\title{
Kinerja Penyuluh Pertanian \\ dan Dampaknya pada Kompetensi Petani Kakao di Empat Wilayah Sulawesi Selatan
}

\section{The Performance Agricultural Extension Workers and their Impact at Competence Cacao Farmers in four District South Sulawesi}

\author{
Sapar $^{1}$, Amri jahi ${ }^{2}$, Pang S. Asngari ${ }^{2}$, Amiruddin $^{2}$, dan I.G. Putu Purnaba ${ }^{2}$ \\ ${ }^{1}$ Sekolah Tinggi Ilmu Ekonomi Muahammadiyah, Palopo, Sulsel \\ ${ }^{2}$ Institut Pertanian Bogor
}

\begin{abstract}
The agricultural extension worker's performance is the work outputs achieved by agricultural extension workers in conducting their jobs. The aim of this research is to know the factors which influence to the agricultural extension worker's performance and the connection between the factors. Also, to know that factors influences the cacao farmers competence. The population of this research is all the agricultural extension workers in four district, South Sulawesi province (447 person). The sample of this research referred to Slovin method from among 106 (one hundred six) agricultural extension workers, 106 (one hundred six) group farmers leaders and 212 (two hundred twelve) cacao farmers. The design of this research was conducted by surveying and interviewing. LISREL program with 'SEM' was used in analyzing data. The Result of this research show that the agricultural extension worker's performance was influenced significantly by characteristic, competence, motivation and self reliance. The total influence of them were 10 percent and 90 percent were represent other influences outside this study. The suggestion was that their performance must be improved by providing special training to improve their capability in agricultural extension planning, monitoring and evaluation, agricultural extension development and technology disemination.
\end{abstract}

Key words: Performance, competencies, motivation

\begin{abstract}
Abstrak
Tujuan penelitian adalah: (1) mengidentifikasi pengaruh faktor-faktor yang berpengaruh pada kinerja penyuluh pertanian, (2) menjelaskan hubungan faktor-faktor yang berpengaruh pada kinerja penyuluh pertanian dan (3) menjelaskan dampak kinerja penyuluh pertanian dan kompetensi ketua kelompok tani pada kompetensi petani kakao di empat wilayah Sulawesi Selatan. Penelitian ini dilaksanakan di empat wilayah Sulawesi Selatan yaitu Kota Palopo, Kabupaten Luwu, Luwu Utara dan Luwu Timur. Pertimbangan empat wilayah ini dijadikan lokasi penelitian karena merupakan representasi wilayah penghasil kakao terbesar di Sulawesi Selatan. Populasi penelitian adalah seluruh penyuluh pertanian di empat wilayah tersebut yaitu berjumlah 447 orang dan petani kakao binaan penyuluh yang terdiri dari ketua kelompok tani dan anggota kelompok tani. Sampel dihitung menggunakan metode Slovin, yakni sebanyak 106 penyuluh pertanian, 106 ketua kelompok tani dan 212 petani kakao. Pengumpulan data melalui survei menggunakan kuisioner. Analisis data menggunakan Structural Equation Model (SEM) dengan program Linear Structural Relationship (LISREL). Hasil penelitian ini menunjukkan bahwa faktor-faktor internal yang berpengaruh pada kinerja penyuluh pertanian adalah kompetensi, motivasi dan kemandirian. Pengaruh secara bersama-sama ketiga peubah tersebut adalah $\left(R^{2}\right) 67$ persen yang nyata pada $\alpha=0,05$.
\end{abstract}

Kata kunci: Kinerja, kompetensi, motivasi

\section{Pendahuluan}

Kinerja penyuluh pertanian yang baik merupakan dambaan setiap stakeholder pertanian. Keadaan petani saat ini yang masih banyak terbelenggu pada kemiskinan merupakan ciri bahwa penyuluhan pertanian masih

\footnotetext{
* Korespondensi Penulis, Telp. 081317040503

E-mail: sapar9@gmail.com
}

perlu untuk terus meningkatkan perannya dalam rangka membantu petani memecahkan masalah mereka sendiri terutama dalam aspek usahatani mereka secara menyeluruh. Hal ini sejalan dengan definisi penyuluhan pertanian itu sendiri sebagai suatu pendidikan nonformal bagi petani dan keluarganya yang bertujuan untuk meningkatkan kesejahteraan petani 
dengan titik fokus pada perubahan pengetahuan, sikap dan keterampilan.

Kondisi penyuluhan pertanian yang terus mengalami perubahan baik sejak pemerintahan orde lama, orde baru sampai orde reformasi turut mempengaruhi citra penyuluhan pertanian. Pada masa orde baru penyuluhan pertanian dicitrakan sebagai alat pemerintah dalam membantu pemerintah menciptakan swasembada pangan dengan pendekatan peningkatan produksi usahatani oleh petani. Penyuluhan pertanian saat itu sangat diperhatikan dan dinilai sukses mengantarkan swasembada pangan. Selanjutnya pada masa orde reformasi, penyuluhan pertanian mengalami masa yang suram terutama dengan perubahan kelembagaan penyuluhan itu sendiri dengan keluarnya undang-undang otonomi daerah yang secara langsung berdampak pada kinerja penyuluh pertanian.

Dengan keluarnya Undang-Undang No. 16 tahun 2006 tentang Sistem Penyuluhan Pertanian, Perikanan dan Kehutanan merupakan suatu peneguhan kembali bahwa penyuluh pertanian mempunyai peran yang sangat strategis dalam rangka memajukan pembangunan pertanian di Indonesia. Pemerintah dan masyarakat umum berkewajiban untuk menyelenggarakan penyuluhan pertanian, perikanan dan kehutanan.

Kinerja penyuluh pertanian sangat dipengaruhi oleh berbagai macam faktor. Pada umumnya, kinerja penyuluh pertanian sangat dipengaruhi peubah individu penyuluh, psikologis dan organisasi yakni penyuluh melakukan tugas-tugas penyuluhan. Peubah individu dapat diklasifikasikan dalam peubah kemampuan dan keterampilan, latar belakang pribadi dan demografis. Selanjutnya peubah psikologis dapat dirumuskan dalam peubah persepsi, sikap, kepribadian, belajar dan motivasi, sedangkan peubah organisasi dapat dibagi dalam peubah sumber daya, kepemimpinan, imbalan, struktur dan desain pekerjaan.

Kinerja penyuluh pertanian ditentukan pada tingkat pencapaian dari tujuan yang telah ditetapkan oleh organisasi penyuluhan pertanian dengan batasan waktu yang telah ditentukan. Pada umumnya, kinerja penyuluh pertanian didasarkan pada tugas pokok dan fungsinya yang diuraikan secara komprehensif pada uraian macam-macam tugas-tugas yang akan dilakukan. Kinerja penyuluh pertanian secara garis besarnya dapat dilihat pada aspek persiapan, pelaksanaan, evaluasi dan pelaporan, pengembangan penyuluhan pertanian dan pengembangan profesi penyuluh pertanian. Selain itu, aspek kepemimpinan, komunikasi, kemitraan usaha dan diseminasi teknologi serta penguasaan terhadap bidang teknis keahlian juga sangat menentukan tingkat keberhasilan seorang penyuluh.

Kinerja penyuluh pertanian pada aspek persiapan, pelaksanaan, evaluasi dan pelaporan merupakan suatu rangkaian yang tersistematis dan terstruktur dalam suatu alur yang tak terpisahkan. Programa penyuluhan pertanian harus berlandaskan pada analisis kebutuhan petani dan mencerminkan kondisi khalayak sasaran saat ini dan kondisi khalayak sasaran yang akan diwujudkan. Oleh karena itu, programa penyuluhan pertanian merupakan cerminan dari proses pembelajaran antara petani dengan penyuluh yang dimulai dengan proses sharing informasi sampai pada keterlibatan aktif dalam hal perencanaan yaitu saat pengidentifikasian potensi wilayah, agroekosistem dan kebutuhan teknologi dengan melibatkan petani.

Aspek berikutnya yang menjadi perhatian bagi seorang penyuluh pertanian setelah programa penyuluhan terbentuk adalah materi dan metode yang akan dipilih untuk melakukan penyuluhan pertanian. Materi dan metode adalah hal yang substansial dalam proses penyuluhan dan disesuaikan dengan kebutuhan petani, keadaan saat itu. Pencapaian tujuan akhir dari kegiatan penyuluhan pertanian ditentukan oleh materi dan metode apa saja yang akan dilakukan oleh seorang penyuluh pertanian. Materi adalah apa-apa saja yang akan disuluhkan sedangkan metode merupakan bagaimana cara yang ditempuh untuk menyampaikan materi tersebut. Oleh karena itu, penyuluh dan petani harus melakukan diskusi dalam hal ini.

Setelah proses penyuluhan berlangsung, maka indikator berikutnya yang dapat dijadikan parameter dalam mengukur kinerja penyuluh pertanian adalah proses pelaporan 
Jurnal Penyuluhan, Maret 2012 Vol. 8 No.1

dan evaluasi dari kegiatan penyuluhan yang telah dilakukan. Pelaporan dan evaluasi dapat dikategorikan dalam dua aspek yaitu pelaporan dari hasil kegiatan penyuluhan yang telah dilakukan dan evaluasi dampak penyuluhan pertanian terhadap petani sebagai khalayak sasaran. Pelaporan dan evaluasi dapat dijadikan sebagai titik untuk melakukan introspeksi diri bagi seorang penyuluh pertanian tentang apa saja yang masih perlu diperbaiki dan apa saja yang telah memenuhi target.

Pengembangan penyuluhan pertanian dan profesi merupakan tindak lanjut dari evaluasi dan pelaporan. Agar kegiatan penyuluhan terus mengikuti perkembangan zaman dan dinamika kehidupan petani, maka seorang penyuluh dituntut untuk terus melakukan proses pembelajaran terutama dalam aspek pedoman dan petunjuk pelaksanaan penyuluhan pertanian dan metode atau sistem kerja penyuluhan pertanian. Selain itu, seorang penyuluh pertanian harus terus menerus menambah input berupa pengetahuan akan ilmu-ilmu penyuluhan terkini lewat pelatihan atau seminar-seminar, karya tulis atau karya ilmiah dan buku-buku yang dapat meningkatkan kapasitas penyuluh pertanian itu sendiri.

Penyuluh yang berhasil adalah penyuluh yang dapat merancang dan melaksanakan suatu program pembelajaran, dimana materi dan metodenya sesuai dengan kondisi dan karakteristik petani. Oleh karena itu, kepemimpinan, komunikasi, diseminasi teknologi dan penguasaan terhadap bidang teknis yang akan disuluhkan harus dikuasai.

Akhirnya dapat disimpulkan bahwa persiapan, pelaksanaan, evaluasi dan pelaporan, pengembangan penyuluhan dan profesi serta aspek kepemimpinan, komunikasi, kemitraan usaha, diseminasi teknologi serta penguasaan terhadap bidang teknis keahlian penyuluh merupakan kegiatan pokok yang harus dilakukan seorang penyuluh pertanian dan dijadikan parameter dalam mengetahui kinerja seorang penyuluh pertanian.

Kinerja penyuluh pertanian sangat dipengaruhi oleh berbagai macam faktor. Pada umumnya, kinerja penyuluh pertanian sangat dipengaruhi peubah individu penyuluh, psikologis dan organisasi yakni penyuluh melakukan tugas-tugas penyuluhan. Peubah individu dapat diklasifikasikan dalam peubah kemampuan dan keterampilan, latar belakang pribadi dan demografis. Selanjutnya peubah psikologis dapat dirumuskan dalam peubah persepsi, sikap, kepribadian, belajar dan motivasi, sedangkan peubah organisasi dapat dibagi dalam peubah sumber daya, kepemimpinan, imbalan, struktur dan desain pekerjaan. Untuk itu penelitian bertujuan: (1) mengidentifikasi pengaruh faktor-faktor internal yang berpengaruh pada kinerja penyuluh pertanian dan (2) menganalisis hubungan faktor-faktor internal yang berpengaruh pada kinerja penyuluh pertanian di empat wilayah Sulawesi Selatan. Penelitian ini diharapkan memperkuat bangunan teori kinerja dalam konteks penyuluhan pertanian dan diharapkan hasil penelitian ini dapat menjadi rujukan pembuatan kebijakan oleh pemerintah pusat maupun pemerintah daerah.

\section{Metode Penelitian}

Penelitian ini dilaksanakan di empat wilayah Sulawesi Selatan yaitu Kota Palopo, Kabupaten Luwu, Luwu Utara dan Luwu Timur dari bulan April sampai Juli 2010. Penentuan lokasi didasarkan pada pertimbangan sebagai representasi sentra produksi kakao di Sulawesi Selatan.

Unit analisisnya adalah penyuluh pertanian yang populasinya adalah 447 orang, ketua kelompok tani dan anggota kelompok tani yang dibina oleh penyuluh. Berdasarkan rumus Slovin dengan tingkat kesalahan delapan koma lima persen, diperoleh sampel berjumlah 106 orang penyuluh diambil secara proporsional random sampling dari Palopo (22 orang), Luwu (34 orang), Luwu Utara (26 orang) dan Luwu Timur (24 orang). Ketua kelompok tani (106 orang) dan petani kakao (212 orang).

Penelitian ini menggunakan metode survei melalui pengisian kuesioner yang didukung wawancara. Validitas instrumen yang digunakan adalah validitas isi (content validity) yang selanjutnya dikonsultasikan kepada lima orang pakar. Hasil perbaikan instru- 
men ini diujicobakan kepada 15 penyuluh pertanian, 15 ketua kelompok tani dan 15 anggota kelompok tani. Dengan menggunakan uji Cronbach Alpha diperoleh koefisien reliabilitas masing-masing sebesar 0,812, 0,782 dan 0,914, yang berarti ketiga instrumen tersebut reliabel. Data yang dikumpulkan kemudian dianalisis menggunakan SEM (Structural Equation Model) dengan program LISREL (Linear Structural Relationships)

\section{Hasil Penelitian}

Model hipotetik yang diajukan mencakup 60 indikator yang berasal dari tiga peubah bebas dan empat peubah terikat. Setelah dilakukan pendugaan peubah yang berpengaruh pada kinerja penyuluh pertanian, ditemukan model struktural kinerja penyuluh pertanian yang menunjukkan jalur pengaruh antar peubah.

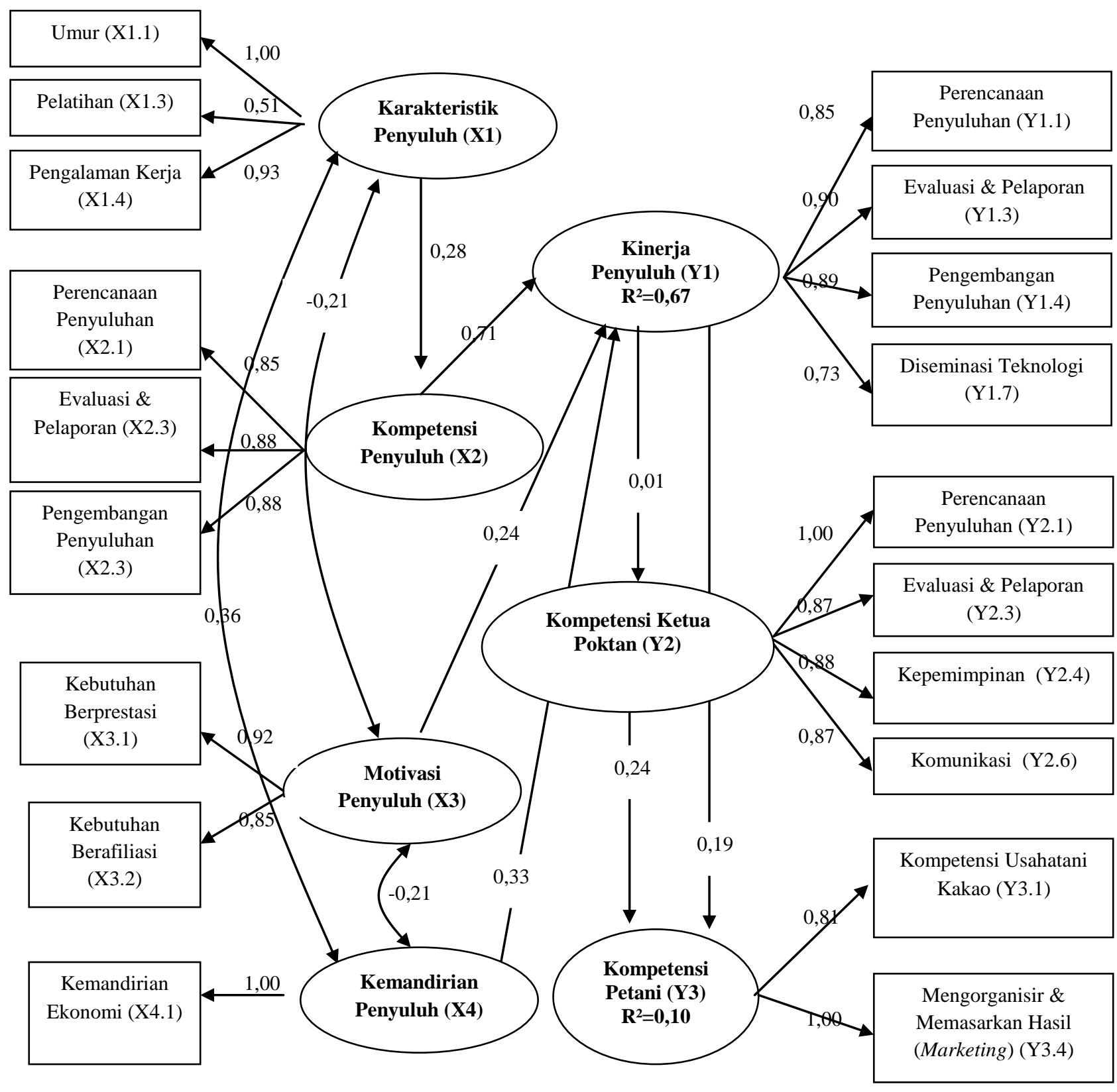

Chi-Square $=163,95, \mathrm{df}=139, p$-hitung $=0,07288, \mathrm{RMSEA}=0,041, \mathrm{CFI}=0,98$

Gambar 1. Estimasi parameter model struktural kinerja penyuluh pertanian 
Jurnal Penyuluhan, Maret 2012 Vol. 8 No.1

Dari model pada Gambar 1 tersebut, dirumuskan persamaan model struktural kinerja pertanian adalah:

$\mathrm{Y} 1=0,71 \mathrm{X} 2+0,24 \mathrm{X} 3+0,33 \mathrm{X} 4$

Keterangan:

$\mathrm{X} 2$ = Kompetensi

X3 = Motivasi

$\mathrm{X} 4=$ Kemandirian

$\mathrm{Y} 1=$ Kinerja Penyuluh

Pertanian

\section{Pengaruh Karakteristik pada Kompetensi Penyuluh Pertanian}

Karakteristik Penyuluh Pertanian berpengaruh nyata pada kompetensi penyuluh pertanian

Untuk menguji Hipotesis 1, Tabel 1 menampilkan koefisien dan $t$-hitung pengaruh peubah karakteristik pada kompetensi penyuluh pertanian sebagai berikut:

Tabel 1. Koefisien dan $t$-hitung pengaruh peubah karakteristik pada kompetensi penyuluh pertanian

\begin{tabular}{lllll}
\hline \multicolumn{2}{c}{ Hubungan antar Peubah } & \multicolumn{4}{c}{$\begin{array}{l}\text { Pengaruh } \\
\text { langsung }\end{array}$} & -hitun! & $\mathbf{R}^{\mathbf{2}}$ \\
\hline $\begin{array}{l}\text { Karakteristik } \\
\text { penyuluh } \rightarrow \begin{array}{l}\text { Kompetensi } \\
\text { penyuluh }\end{array}\end{array}$ & 0,28 & 2,85 & 0,08 \\
\hline Keterangan: $\underline{t} 0,05$ tabel $=1,96$ & & &
\end{tabular}

Tabel 1 menunjukkan pengaruh langsung peubah karakteristik penyuluh pada kompetensi penyuluh pertanian sebesar 0,28. Koefisien pengaruh tersebut nyata pada pada $\alpha=0,05$. Secara matematik persamaan model struktural kompetensi penyuluh pertanian adalah: X2 = 0,28 X1; X2 merupakan kompetensi penyuluh dan X1 karakteristik penyuluh.

\section{Pengaruh Kompetensi, Motivasi dan Kemandirian pada Kinerja Penyuluh Pertanian}

Kompetensi, Motivasi dan Kemandirian Penyuluh Pertanian berpengaruh nyata pada kinerja penyuluh pertanian

Untuk menguji Hipotesis 2, Tabel 2 menampilkan koefisien dan $t$-hitung pengaruh peubah kompetensi, motivasi dan kemandirian pada kinerja penyuluh pertanian sebagai berikut:
Tabel 2. Koefisien dan $t$-hitung pengaruh peubah kompetensi, motivasi dan kemandirian pada kinerja penyuluh pertanian

\begin{tabular}{|c|c|c|c|c|}
\hline \multicolumn{2}{|c|}{ Hubungan antar Peubah } & \multirow{2}{*}{$\begin{array}{c}\text { Pengaruh } \\
\text { langsung } \\
0,71 \\
\end{array}$} & \multirow{2}{*}{$\begin{array}{c}t- \\
\text { hitung } \\
10,6 \\
4 \\
\end{array}$} & \multirow{4}{*}{$\begin{array}{c}\mathbf{R}^{2} \\
67 \%\end{array}$} \\
\hline $\begin{array}{l}\text { Kompetensi } \\
\text { penyuluh }\end{array}$ & $\rightarrow \begin{array}{l}\text { Kinerja } \\
\text { penyuluh }\end{array}$ & & & \\
\hline $\begin{array}{l}\text { Motivasi } \\
\text { penyuluh }\end{array}$ & $\rightarrow \begin{array}{l}\text { Kinerja } \\
\text { penyuluh }\end{array}$ & 0,24 & 3,52 & \\
\hline $\begin{array}{l}\text { Kemandirian } \\
\text { penyuluh }\end{array}$ & $\rightarrow \begin{array}{l}\text { Kinerja } \\
\text { penyuluh }\end{array}$ & 0,33 & 4,95 & \\
\hline
\end{tabular}

Keterangan: $t$ 0,05 tabel $=1,96$

Tabel 2 menunjukkan pengaruh langsung peubah kompetensi, motivasi dan kemandirian penyuluh pada kinerja penyuluh pertanian, secara beurutan, yaitu: 0,$71 ; 0,24$ dan 0,33 . Ketiga koefisien pengaruh tersebut nyata pada pada $\alpha=0,05$. Secara matematik persamaan model struktural kinerja penyuluh pertanian adalah: $\mathrm{Y} 1=0,71 \mathrm{X} 2+0,24 \mathrm{X} 3+$ 0,33 X4; Y1 merupakan kinerja penyuluh; X2 kompetensi penyuluh; X3 motivasi penyuluh dan X4 kemandirian penyuluh.

Tabel 2 juga menunjukkan pengaruh ketiga peubah tersebut secara bersama-sama pada kinerja penyuluh pertanian sebesar 67 persen yang nyata pada $\alpha=0,05$.

\section{Pengaruh Karakteristik, Kompetensi, Motivasi, Kemandirian dan Kinerja Penyuluh Pertanian pada Kompetensi Ketua Kelompok Tani}

Karakteristik, kompetensi, motivasi, kemandirian dan kinerja penyuluh Pertanian berpengaruh nyata pada kompetensi ketua kelompok tani

Untuk menguji Hipotesis 3, Tabel 3 menampilkan koefisien dan $t$-hitung pengaruh peubah karakteristik, kompetensi, motivasi, kemandirian dan kinerja penyuluh pertanian pada kompetensi ketua kelompok tani adalah sebagai berikut:

Tabel 3 menunjukkan tidak adanya adanya pengaruh peubah karakteristik, kompetensi, motivasi, kemandirian dan kinerja penyuluh pada kompetensi ketua kelompok tani, yaitu: 0,$00 ; 0,00 ; 0,00 ; 0,00$ dan 0,01 yang tidak nyata pada $\alpha=0,05$.

Karakteristik, kompetensi, motivasi dan kemandirian berpengaruh tidak langsung, 
sedangkan kinerja penyuluh pertanian berpengaruh langsung pada kompetensi ketua kelompok tani, sehingga secara matematik persamaan model struktural kompetensi ketua kelompok tani adalah: Y2 $=0,01 \mathrm{Y} 1$, dimana Y2 merupakan kompetensi ketua kelompok tani dan Y1 merupakan kinerja penyuluh pertanian. Jadi Hipotesis 3 ditolak.

Tabel 3. Koefisien dan $t$-hitung pengaruh peubah karakteristik, kompetensi, motivasi, kemandirian dan kinerja penyuluh pada kompetensi ketua kelompok tani

\begin{tabular}{|c|c|c|c|c|}
\hline & \multirow{2}{*}{ Hubungan antar Peubah } & \multicolumn{2}{|c|}{$\begin{array}{c}\text { Total } \\
\text { Koefisien } \\
\text { Pengaruh }\end{array}$} & \multirow[t]{2}{*}{$\begin{array}{c}t- \\
\text { hitung }\end{array}$} \\
\hline & & $\begin{array}{l}\text { Lang- } \\
\text { sung }\end{array}$ & $\begin{array}{l}\text { Tdk } \\
\text { lang- } \\
\text { sung }\end{array}$ & \\
\hline $\begin{array}{l}\text { Karakteristi } \\
\text { k penyuluh }\end{array}$ & $\rightarrow \begin{array}{l}\text { Kompetensi ketua } \\
\text { kelompok tani }\end{array}$ & - & 0,00 & 0,10 \\
\hline $\begin{array}{l}\text { Kompetensi } \\
\text { penyuluh }\end{array}$ & $\rightarrow \begin{array}{l}\text { Kompetensi ketua } \\
\text { kelompok tani }\end{array}$ & - & 0,00 & 0,10 \\
\hline $\begin{array}{l}\text { Motivasi } \\
\text { penyuluh }\end{array}$ & $\rightarrow \begin{array}{l}\text { Kompetensi ketua } \\
\text { kelompok tani }\end{array}$ & - & 0,00 & 0,10 \\
\hline $\begin{array}{l}\text { Kemandirian } \\
\text { penyuluh }\end{array}$ & $\begin{array}{l}\text { Kompetensi ketua } \\
\text { kelompok tani }\end{array}$ & - & 0,00 & 0,10 \\
\hline $\begin{array}{l}\text { Kinerja } \\
\text { penyuluh }\end{array}$ & $\begin{aligned} \rightarrow & \text { Kompetensi ketua } \\
& \text { kelompok tani }\end{aligned}$ & 0,01 & - & 0,10 \\
\hline
\end{tabular}

Keterangan: $\underline{t} 0,05$ tabel $=1,96$

\section{Pengaruh Karakteristik, Kompetensi, Motivasi, Kemandirian, Kinerja Penyuluh Pertanian dan Ketua Kelompok Tani pada Kompetensi Petani Kakao}

Karakteristik, kompetensi, motivasi, kemandirian, kinerja penyuluh pertanian dan kompetensi ketua kelompok tani berpengaruh nyata pada kompetensi petani kakao

Untuk menguji Hipotesis 4, Tabel 4 menampilkan koefisien dan $t$-hitung pengaruh peubah karakteristik, kompetensi, motivasi, kemandirian, kinerja penyuluh pertanian dan kompetensi ketua kelompok tani pada kompetensi petani kakao. Tabel 4 menunjukkan pengaruh peubah karakteristik, kompetensi, motivasi, kemandirian, kinerja penyuluh dan kompetensi ketua kelompok tani pada kompetensi petani kakao, secara berurutan, yaitu: 0,$03 ; 0,12 ; 0,04 ; 0,05 ; 0,19$ dan 0,24 . Peubah kompetensi penyuluh, kinerja penyuluh dan kompetensi ketua kelompok tani pada kompetensi petani kakao berpengaruh nyata pada pada $\alpha=0,05$, sedangkan peubah karak- teristik, motivasi dan kemandirian penyuluh pada kompetensi petani kakao tidak berpengaruh nyata pada pada $\alpha=0,05$.

Tabel 4. Koefisien dan $t$-hitung pengaruh peubah karakteristik, kompetensi, motivasi, kemandirian, kinerja penyuluh dan kompetensi ketua kelompok tani pada kompetensi petani kakao

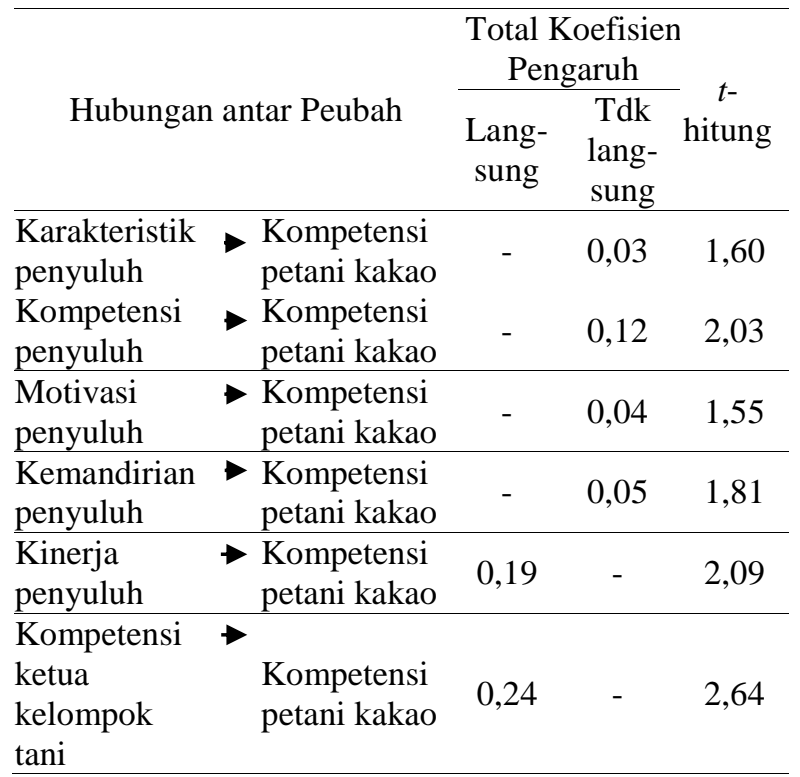

Keterangan: $\underline{t} 0,05$ tabel $=1,96$

Karakteristik, kompetensi, motivasi, kemandirian berpengaruh tidak langsung, sedangkan kinerja penyuluh pertanian dan kompetensi ketua kelompok tani berpengaruh langsung pada kompetensi petani kakao, sehingga secara matematik persamaan model struktural kompetensi petani kakao adalah: Y3 $=0,19 \mathrm{Y} 1+0,24 \mathrm{Y} 2$; Y3 merupakan kompetensi petani kakao, Y2 merupakan kompetensi ketua kelompok tani dan Y1 merupakan kinerja penyuluh pertanian.

\section{Pengaruh Kinerja Penyuluh Pertanian dan Ketua Kelompok Tani pada Kompetensi Petani Kakao}

Kinerja penyuluh pertanian dan kompetensi ketua kelompok tani berpengaruh nyata pada kompetensi petani kakao

Untuk menguji Hipotesis 5, Tabel 5 menampilkan koefisien dan $t$-hitung pengaruh peubah kinerja penyuluh pertanian, kompetensi ketua kelompok tani pada kompetensi petani kakao. Tabel 5 menunjukkan pengaruh 
Jurnal Penyuluhan, Maret 2012 Vol. 8 No.1

peubah kinerja penyuluh pertanian dan kompetensi ketua kelompok tani pada kompetensi petani kakao secara berurutan, yaitu 0,19 dan 0,24 yang nyata pada $\alpha=0,05$

Tabel 5. Koefisien dan $t$-hitung pengaruh peubah kinerja penyuluh pertanian dan kompetensi ketua kelompok tani pada kompetensi petani kakao

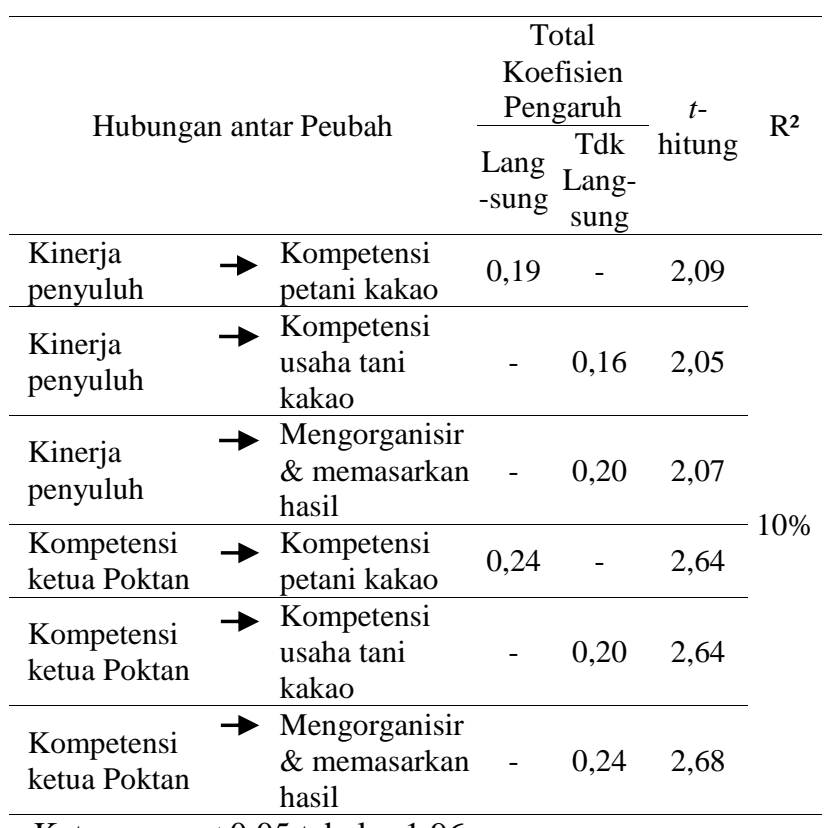

Keterangan: $\underline{t} 0,05$ tabel $=1,96$

Kinerja penyuluh pertanian dan kompetensi ketua kelompok tani berpengaruh langsung pada kompetensi petani kakao, sehingga secara matematik persamaan model struktural kompetensi petani kakao adalah: Y3 $=0,19 \mathrm{Y} 1+0,24 \mathrm{Y} 2$, dimana Y3 merupakan kompetensi petani kakao, Y2 merupakan kompetensi ketua kelompok tani dan Y1 merupakan kinerja penyuluh pertanian

\section{Hubungan Karakteristik, Motivasi dan Kemandirian Penyuluh Pertanian}

Terdapat hubungan antar peubah karakteristik, motivasi dan kemandirian penyuluh pertanian

Untuk menguji Hipotesis 6, Tabel 6 menampilkan arah dan $t$-hitung hubungan peubah karakteristik, motivasi, dan kemandirian penyuluh pertanian. Tabel 6 menunjukkan koefisien korelasi dan $t$-hitung antar peubah, peubah karakteristik dengan motivasi, peubah karakteristik dengan kemandirian, dan moti- vasi dengan kemandirian penyuluh pertanian secara beurutan, yaitu: - 0,$21 ;+0,36$; dan 0,21 . Ketiga koefisien hubungan tersebut nyata pada $\alpha=0,05$.

Kompetensi dengan kemandirian penyuluh memiliki koefisien korelasi - 0,03 dan $t$-hitung $-0,31$ yang tidak nyata pada $\alpha=0,05$. Jadi Hipotesis 6 diterima pada hubungan antar peubah karakteristik dengan kompetensi, karakteristik dengan motivasi, karakteristik dengan kemandirian, kompetensi dengan motivasi dan motivasi dengan kemandirian penyuluh

\section{Tabel 6. Koefisien korelasi dan $t$-hitung peubah karakteristik, motivasi dan kemandirian penyuluh pertanian}

\begin{tabular}{llll}
\hline \multicolumn{2}{c}{ Hubungan antar Peubah } & $\begin{array}{c}\text { Koefisien } \\
\text { Korelasi }\end{array}$ & t-hitung \\
\hline $\begin{array}{l}\text { Karakteristik } \\
\text { penyuluh }\end{array}$ & $\begin{array}{l}\text { Motivasi } \\
\text { penyuluh }\end{array}$ & $-0,21$ & $-2,11$ \\
\hline $\begin{array}{l}\text { Karakteristik } \\
\text { penyuluh }\end{array}$ & $\begin{array}{l}\text { Kemandirian } \\
\text { penyuluh }\end{array}$ & $+0,36$ & 4,34 \\
\hline $\begin{array}{l}\text { Motivasi } \\
\text { penyuluh }\end{array}$ & $\begin{array}{l}\text { Kemandirian } \\
\text { penyuluh }\end{array}$ & $-0,21$ & $-2,15$ \\
\hline
\end{tabular}

Keterangan: $\underline{t} 0,05$ tabel $=1,96$

\section{Pembahasan}

\section{Pengaruh Karakteristik pada Kompetensi Penyuluh Pertanian}

Hasil penelitian menunjukkan bahwa peubah karakteristik berpengaruh nyata pada kompetensi penyuluh pertanian. Hal ini berarti karakteristik penyuluh pertanian ikut menentukan baik buruknya kompetensi mereka dengan koefisien pengaruh sebesar 0,28 yang nyata pada $\alpha=0,05$. Pengaruh karakteristik pada kompetensi penyuluh pertanian nampak pada baik-buruknya kinerja penyuluh melakukan perencanaan penyuluhan, evaluasi dan pelaporan penyuluhan, pengembangan penyuluhan pertanian dan diseminasi teknologi. Hal ini mengindikasikan, jika terjadi peningkatan satu satuan karakteristik penyuluh pertanian, akan meningkatkan hasil kerja perencanaan penyuluhan sebesar 0,24 satuan, evaluasi dan laporan penyuluhan sebesar 0,25 satuan dan pengembangan penyuluhan pertanian sebesar 0,25.

Hasil penelitian ini sejalan dengan penelitian Bank Dunia (Hadi, 2000) menyatakan bahwa, kinerja PPL sangat rendah, hal ini 
antara lain ditunjukkan oleh: (1) bekal pengetahuan dan keterampilan penyuluh sangat kurang, seringkali tidak cocok dengan kebutuhan petani, (2) PPL sangat kurang dipersiapkan dan kurang dilatih untuk melakukan kegiatan penyuluhan pertanian. Bila PPL dilatih, maka kebanyakan latihan-latihan itu tidak relevan dengan tugasnya sebagai PPL di wilayah kerjanya dan (3) dalam banyak hal, PPL telah ketinggalan informasi dari petani dan nelayan yang dilayaninya.

Secara teoritis penelitian ini sejalan dengan pendapat Robbins (1996) menjelaskan beberapa karakteristik individu yang meliputi umur, jenis kelamin, status perkawinan, banyaknya tanggung jawab dan pengalaman kerja mempunyai efek terhadap kinerja. Karakteristik individu tersebut akan menjadikan seseorang berperilaku positif yang berarti disiplin, dan sebaliknya jika tidak sesuai cenderung berperilaku tidak disiplin.

\section{Pengaruh Kompetensi pada Kinerja Penyuluh Pertanian}

Hasil penelitian menunjukkan bahwa peubah kompetensi penyuluh pertanian berpengaruh nyata pada kinerja mereka. Hal ini berarti kompetensi penyuluh pertanian ikut menentukan baik buruknya kinerja mereka dengan koefisien pengaruh sebesar 0,71 yang nyata pada $\alpha=0,05$. Pengaruh kompetensi pada kinerja penyuluh pertanian tersebut nampak pada baik buruknya perencanaan penyuluhan, evaluasi dan pelaporan penyuluhan, pengembangan penyuluhan dan diseminasi teknologi. Hal ini mengindikasikan, jika terjadi peningkatan satu satuan kompetensi penyuluh pertanian, akan meningkatkan hasil kerja perencanaan penyuluhan sebesar 0,60 satuan, evaluasi dan laporan penyuluhan sebesar 0,64 satuan, pengembangan penyuluhan pertanian sebesar 0,64 serta diseminasi teknologi sebesar 0,52 satuan.

Hasil penelitian ini sejalan dengan hasil penelitian Teddy Rachmat Muliady (2009) tentang faktor-faktor yang berpengaruh pada kinerja penyuluh pertanian dan dampaknya pada perilaku petani padi di tiga kabupaten Jawa Barat, menyimpulkan bahwa kompetensi penyuluh berpengaruh secara positif pada kinerja mereka dengan koefisien pengaruh sebesar 0,40 yang nyata pada $\alpha=0,05$. Bestina Supriyanto (2006) tentang kinerja penyuluh pertanian dalam pengembangan agribisnis nenas di kecamatan Tambang, kabupaten Ampar, menyimpulkan bahwa kompetensi penyuluh berpengaruh secara positif pada kinerja mereka dengan koefisien pengaruh sebesar 0,127 yang nyata pada $\alpha=0,05$.

Secara teoritis penelitian ini juga sejalan dengan pendapat Robbins (Veithzal Revai 2004) yang menyatakan bahwa kinerja sebagai fungsi interaksi antara kemampuan atau ability (A), motivasi atau motivation (M) dan kesempatan atau opportunity (O), yaitu kinerja $=f(\mathrm{~A} \times \mathrm{M} \times \mathrm{O})$. Artinya: kinerja merupakan fungsi dari kemampuan, motivasi dan kesempatan. Dengan demikian, kinerja ditentukan oleh faktor-faktor kemampuan, motivasi dan kesempatan. Siagian (2002) mengemukakan rumus $\mathrm{P}=\mathrm{M} \times \mathrm{K} \times \mathrm{T}$, dimana $\mathrm{P}$ adalah performance atau kinerja, $\mathrm{M}$ adalah motivasi, $\mathrm{K}$ adalah kemampuan dan $\mathrm{T}$ adalah tugas yang tepat. Gibbson (1996) menyatakan bahwa kinerja individu pegawai dipengaruhi oleh faktor motivasi, kemampuan dan lingkungan kerja. Sedangkan Atmosoeprapto (2000) menyatakan bahwa kinerja (performance) merupakan fungsi dari motivasi dan kemampuan yang merupakan dua faktor yang dapat menimbulkan efek sinergik. Kemampuan yang tinggi dan didukung oleh motivasi yang tinggi pula akan memberikan keragaan yang baik berupa produktivitas yang lebih baik (produktif).

\section{Pengaruh Motivasi pada Kinerja Penyuluh Pertanian}

Hasil penelitian menunjukkan bahwa peubah motivasi penyuluh pertanian berpengaruh nyata pada kinerja mereka. Hal ini berarti motivasi penyuluh pertanian ikut menentukan baik buruknya kinerja mereka dengan koefisien pengaruh sebesar 0,24 yang nyata pada $\alpha=0,05$. Pengaruh motivasi pada kinerja penyuluh pertanian tersebut nampak pada baik buruknya perencanaan penyuluhan, evaluasi dan pelaporan penyuluhan, pengembangan penyuluhan dan diseminasi teknologi. Hal ini mengindikasikan, jika terjadi peningkatan satu satuan motivasi penyuluh pertanian, akan 
Jurnal Penyuluhan, Maret 2012 Vol. 8 No.1

meningkatkan hasil kerja perencanaan penyuluhan sebesar 0,20 satuan, evaluasi dan laporan penyuluhan sebesar 0,21 satuan, pengembangan penyuluhan pertanian sebesar 0,21 serta diseminasi teknologi sebesar 0,17 satuan.

Hasil penelitian ini sejalan dengan hasil penelitian Teddy Rachmat Muliady (2009) tentang faktor-faktor yang berpengaruh pada kinerja penyuluh pertanian dan dampaknya pada perilaku petani padi di tiga kabupaten Jawa Barat, menyimpulkan bahwa motivasi penyuluh berpengaruh secara positif pada kinerja mereka dengan koefisien pengaruh sebesar 0,27 yang nyata pada $\alpha=0,05$. Penelitian Bestina Supriyanto (2006) tentang kinerja penyuluh pertanian dalam pengembangan agribisnis nenas di kecamatan Tambang, kabupaten Ampar, menyimpulkan bahwa motivasi penyuluh berpengaruh secara positif pada kinerja mereka dengan koefisien pengaruh sebesar 0,513 yang nyata pada $\alpha=0,05$

Secara teoritis penelitian ini juga sejalan dengan pendapat Atmosoeprapto (2000) yang menyatakan bahwa kinerja (performance) merupakan fungsi dari motivasi dan kemampuan, dua faktor yang dapat menimbulkan efek sinergik. Kemampuan yang tinggi dan didukung oleh motivasi yang tinggi pula akan memberikan keragaan yang baik berupa produktivitas yang lebih baik. Selain itu Robert L. Mathis dan John H. Jackson (Wikipedia 2009) menyatakan bahwa faktor-faktor yang mempengaruhi kinerja individu tenaga kerja, yaitu: (1) kemampuan mereka, (2) motivasi, (3) dukungan yang diterima, (4) keberadaan pekerjaan yang mereka lakukan, dan (5) hubungan mereka dengan organisasi. Menurut Kopelman (Cokroaminoto 2007), peubah imbalan akan berpengaruh terhadap peubah motivasi, yang pada akhirnya secara langsung mempengaruhi kinerja individu.

\section{Pengaruh Kemandirian pada Kinerja Penyuluh Pertanian}

Hasil penelitian menunjukkan bahwa peubah kemandirian penyuluh pertanian berpengaruh nyata pada kinerja mereka. Hal ini berarti kemandirian penyuluh pertanian ikut menentukan baik buruknya kinerja mereka dengan koefisien pengaruh sebesar 0,33 yang nyata pada $\alpha=0,05$. Pengaruh kemandirian pada kinerja penyuluh pertanian tersebut nampak pada baik buruknya perencanaan penyuluhan, evaluasi dan pelaporan penyuluhan, pengembangan penyuluhan dan diseminasi teknologi. Hal ini mengindikasikan, jika terjadi peningkatan satu satuan kemandirian penyuluh pertanian, akan meningkatkan hasil kerja perencanaan penyuluhan sebesar 0,28 satuan, evaluasi dan laporan penyuluhan sebesar 0,30 satuan, pengembangan penyuluhan pertanian sebesar 0,29 serta diseminasi teknologi sebesar 0,24 satuan.

Hasil penelitian ini sejalan dengan hasil penelitian Mardin (2009) tentang faktorfaktor yang berpengaruh pada kemandirian nelayan ikan demarsal di kecamatan WangiWangi Selatan provinsi Sulawesi Tenggara, menyimpulkan bahwa pengalaman nelayan, sifat perintis nelayan dan kompetensi nelayan berpengaruh secara bersama-sama pada kemandirian mereka dengan koefisien determinasi sebesar 54,5 persen yang nyata pada $\alpha=0,05$. Lainnya adalah hasil penelitian Marliati (2008) tentang pemberdayaan petani untuk pemenuhan kebutuhan pengembangan petani beragribisnis di kabupaten Kampar provinsi Riau, yang menyimpulkan bahwa tingkat pemenuhan kebutuhan pengembangan petani beragribisnis, kinerja penyuluh pertanian memberdayakan petani, karakteristik petani (pendidikan formal dan non formal) secara bersama-sama berpengaruh langsung pada kemandirian petani beragribisnis dengan koefisien determinasi sebesar 95 persen yang nyata pada $\alpha=0,05$. Hasil penelitian Mohammad Ikbal Bahua (2010) tentang faktor-faktor yang mempengaruhi kinerja penyuluh pertanian dan dampaknya pada perilaku petani jagung di Provinsi Gorontalo menyatakan bahwa kemandirian penyuluh pertanian ikut menentukan secara langsung baik buruknya kinerja mereka dengan koefisien pengaruh sebesar $-0,31$ yang nyata pada $\alpha=0,05$.

Secara teoritis, hasil penelitian ini sejalan dengan pendapat Godfrey (2003) menyatakan bahwa, kemandirian ekonomi merupakan kemampuan dari suatu entitas untuk menopang kesejahteraannya. Entitas dapat 
berupa: individu, keluarga, komunitas, negara atau bangsa. Kemandirian ekonomi merupakan tujuan antara (intermediate end) yang memfasilitasi suatu entitas untuk mencapai visi mereka pada kehidupan yang lebih baik. Havighurst (1974) menjelaskan bahwa, kemandirian intelektual mencakup pengertian kebebasan untuk bertindak, tidak tergantung kepada orang lain, tidak terpengaruh lingkungan dan bebas mengatur kebutuhan sendiri. Kemandirian sosial merupakan suatu sikap individu yang diperoleh secara kumulatif selama perkembangan. Individu akan terus belajar untuk bersikap mandiri dalam menghadapi berbagai situasi di lingkungan, sehingga individu pada akhirnya akan mampu berpikir dan bertindak sendiri. Dengan kemandiriannya seseorang dapat memilih jalan hidupnya untuk dapat berkembang dengan lebih baik.

\section{Pengaruh Bersama Kompetensi, Motivasi dan Kemandirian pada Kinerja Penyuluh Pertanian}

Hasil penelitian menunjukkan bahwa peubah kompetensi, motivasi dan kemandirian penyuluh pertanian berpengaruh secara positif pada kinerja mereka, dengan koefisien determinasi $\left(\mathrm{R}^{2}\right)$ sebesar 0,67 . Hal ini berarti bahwa peubah-peubah tersebut secara bersamasama berpengaruh pada kinerja penyuluh pertanian sebesar 67 persen, dan sisanya sebesar 33 persen merupakan pengaruh peubah lain yang tidak termasuk dalam penelitian ini.

Pengaruh bersama peubah kompetensi, motivasi dan kemandirian pada kinerja penyuluh pertanian yakni 67 persen, sedangkan sisanya sebesar 33 persen dipengaruhi oleh peubah lain. Oleh karena koefisien determinasi $\left(\mathrm{R}^{2}\right)$ kinerja penyuluh pertanian sebesar 67 persen masih sangat mungkin untuk ditingkatkan. Peningkatan kinerja penyuluh pertainan dapat dilakukan melalui dua cara, yaitu: (1) peningkatan pada dimensi-dimensi peubah yang berpengaruh nyata pada kinerja penyuluh, seperti kemampuan merencanakan penyuluhan, kemampuan evaluasi dan pelaporan penyuluhan, kemampuan mengembangkan penyuluhan, kebutuhan untuk berprestasi, kebutuhan untuk berafiliasi serta kemandirian ekonomi dan (2) pengelolaan yang lebih baik pada dimensi-dimensi peubah yang belum memberikan kontribusi nyata pada kinerja penyuluh, sehingga diharapkan dengan pengelolaan yang lebih baik akan berdampak pada peningkatan kinerja mereka.

\section{Pengaruh Karakteristik, Kompetensi, Motivasi, Kemandirian, Kinerja Penyuluh Pertanian dan Kompetensi Ketua Kelompok Tani pada Kompetensi Petani Kakao}

Hasil penelitian menunjukkan bahwa peubah karakteristik, kompetensi, motivasi, kemandirian, kinerja penyuluh pertanian dan kompetensi ketua kelompok tani berpengaruh secara nyata pada kompetensi petani kakao. Hal ini berarti karakteristik, kompetensi, motivasi, kemandirian, kinerja penyuluh pertanian dan kompetensi ketua kelompok tani ikut menentukan ada tidaknya perubahan pada kompetensi petani kakao. Namun pengaruh karakteristik, kompetensi, motivasi dan kemandirian penyuluh pertanian pada kompetensi petani kakao merupakan pengaruh tidak langsung, artinya pengaruh keempat peubah tersebut pada kompetensi petani kakao terjadi melalui kinerja mereka. Sedangkan pengaruh kinerja penyuluh pertanian dan kompetensi ketua kelompok tani merupakan pengaruh langsung dengan persamaan model struktural $\mathrm{Y} 3=0,19 \mathrm{Y} 1+0,24 \mathrm{Y} 2$.

Persamaan diatas mengindikasikan bila terjadi peningkatan satu satuan kinerja penyuluh pertanian, maka akan terjadi perubahan kompetensi petani kakao sebesar 0,19 satuan, begitupun apabila terjadi peningkatan satu satuan kompetensi ketua kelompok tani, maka akan terjadi perubahan kompetensi petani kakao sebesar 0,24 satuan. Perubahan pada kompetensi petani kakao akan nampak pada perubahan kompetensi usahatani kakao dan kemampuan mengorganisir dan memasarkan hasil. Koefisien determinasi kinerja penyuluh dan kompetensi ketua kelompok tani pada kompetensi petani kakao sebesar 10 persen dan sisanya 90 persen merupakan peubah lain yang tidak dapat dijelaskan oleh model penelitian. 
Jurnal Penyuluhan, Maret 2012 Vol. 8 No.1

Penyuluhan pertanian merupakan proses perubahan perilaku petani kearah yang lebih baik melalui suatu sistem pendidikan, namun demikian kegiatan penyuluhan bukanlah satu-satunya penyebab terjadinya perubahan tersebut. Lionberger dan Gwin (Mardikanto 1993) menyatakan bahwa kegiatan penyuluhan pertanian merupakan salah satu diantara sekian banyak peubah yang menyebabkan terjadinya perubahan perilaku perilaku tani dalam berusahatani. Hal ini ditunjukkan oleh penelitian Yusuf (2008) yang menyatakan bahwa faktor-faktor yang berpengaruh pada perilaku petani adalah motivasi petani mencapai keberhasilan, wawasan petani, keaktifan petani mencari informasi, dan intensitas penyuluhan. Penelitian Otto Iskandar (2002) menyatakan bahwa secara bersama-sama etos kerja, motivasi keberhasilan, dan sikap inovatif berpengaruh secara positif terhadap produktivitas petani. Sejalan dengan pendapat tersebut diatas, Soedijanto (2004) menyatakan bahwa dengan kinerja penyuluh pertanian yang tinggi sebagai pemandu, akan terjadi proses belajar pada diri petani dalam berusahatani.

Hasil penelitian ini menyatakan bahwa koefisien determinasi kinerja penyuluh pertanian dan kompetensi ketua kelompok tani sebesar 10 persen, yang berarti angka kontribusi kinerja penyuluh dan kompetensi ketua kelompok tani masih rendah. Dengan demikian, perhatian dan peningkatan pada kinerja penyuluh dan ketua kelompok tani masih harus ditingkatkan dengan memperhatikan karakteristik, kompetensi, motivasi dan kemandirian mereka sehingga memiliki arti yang sangat strategis dalam peningkatan produksi kakao, sebab perubahan kompetensi petani kakao kearah yang lebih baik akan berdampak pada peningkatan produktivitas usahatani.

\section{Hubungan Antar Faktor yang Berpengaruh pada Kinerja Penyuluh}

Hasil penelitian menunjukkan terdapat hubungan diantara ketiga peubah independen, yaitu karakteristik, motivasi dan kemandirian penyuluh pertanian. Hasil penelitian ini sejalan dengan pendapat Lusthaus (2002) yang menyatakan bahwa kinerja organisasi dipengaruhi oleh tiga faktor, yaitu kapasitas organisasi, motivasi organisasi dan lingkungan organisasi dan masing-masing memiliki keterkaitan satu dengan yang lainnya.

Hubungan karakteristik dan motivasi bersifat negatif, artinya perubahan yang terjadi pada karakteristik penyuluh akan diikuti pula perubahan berlawanan pada motivasinya. Namun keeratan hubungan kedua peubah tersebut tergolong lemah, hal ini ditunjukkan oleh koefisien hubungan sebesar 0,21, yang lebih kecil dari 0,5. Dengan demikian bila umur, pelatihan dan pengalaman kerja penyuluh pertanian bertambah, maka akan diikuti pula turunnya motivasi mereka dalam hal kebutuhan untuk berprestasi dan kebutuhan untuk berafiliasi.

Hubungan karakteristik dan kemandirian bersifat positif, artinya perubahan yang terjadi pada karakteristik penyuluh akan diikuti pula oleh perubahan searah pada kemandirian penyuluh begitupun sebaliknya. Namun keeratan hubungan kedua peubah tersebut tergolong lemah, hal ini ditunjukkan oleh koefisien hubungan sebesar 0,36, yang lebih kecil dari 0,5. Dengan demikian bila umur, pelatihan dan pengalaman kerja penyuluh pertanian bertambah, maka akan diikuti pula peningkatan kemandirian mereka dalam hal kemandirian ekonomi.

Hubungan motivasi dan kemandirian bersifat negatif, artinya perubahan yang terjadi pada motivasi penyuluh akan diikuti pula oleh perubahan berlawanan pada kemandirian penyuluh begitupun sebaliknya. Namun keeratan hubungan kedua peubah tersebut tergolong lemah, hal ini ditunjukkan oleh koefisien hubungan sebesar 0,21, yang lebih kecil dari 0,5 . Dengan demikian bila kebutuhan untuk berprestasi dan kebutuhan untuk berafiliasi bertambah, maka akan diikuti pula penurunan kemandirian ekonomi

\section{Kesimpulan}

Berdasarkan hasil analisis dan pembahasan, maka dapat dirumuskan kesimpulan sebagai berikut: (1) faktor-faktor yang berpengaruh pada kinerja penyuluh pertanian adalah kompetensi penyuluh (kemampuan pe- 
rencanaan penyuluhan, kemampuan dalam evaluasi dan pelaporan, kemampuan dalam pengembangan penyuluhan), motivasi penyuluh (kebutuhan untuk berprestasi, kebutuhan untuk berafiliasi) dan kemandirian (kemandirian ekonomi). Pengaruh ketiga faktor tersebut pada kinerja penyuluh pertanian adalah 0,$75 ; 0,24$ dan 0,33 dengan koefisien determinasi sebesar 67 persen, (2) terdapat hubungan antara faktor-faktor yang berpengaruh pada kinerja penyuluh pertanian, yaitu karakteristik dengan motivasi, karakteristik dengan kemandirian, dan motivasi dengan kemandirian. Hubungan ketiga faktor-faktor tersebut adalah lemah, dan (3) dampak kinerja penyuluh pertanian (perencanaan penyuluhan, evaluasi dan pelaporan penyuluhan, pengembangan penyuluhan dan diseminasi teknologi) serta kompetensi ketua kelompok tani melalui kemampuan merencanakan penyuluhan, kemampuan mengevaluasi dan melaporkan penyuluhan, kemampuan kepemimpinan dan kemampuan komunikasi ketua kelompok tani pada kompetensi petani kakao adalah 10 persen dengan koefisien pengaruh masingmasing sebesar 0,19 dan 0,24.

\section{Daftar Pustaka}

Atmosoeprapto K. 2000. Menuju SDM Berdaya: Dengan Kepemimpinan Efektif dan Manajemen Efisien. Jakarta: Alex Media Komputindo

Answorth M, Amiruddin S. 2002. Managing Performance People. Terjemahan. Jakarta: PT. Bhuana Ilmu Populer.

Bestina S, Slamet H, Amiruddin S. 2006. Kinerja Penyuluh Pertanian dalam Pengembangan Agribisnis Nenas di Kecamatan Tambang, Kabupaten Kampar. Laporan Hasil Penelitian. Kendari: Balai Pengkajian Teknologi Pertanian Kendari.

Gibson JL. 2001. Cooperative Extension Program Planning in Wisconsin. USA. University of Wisconsin.

Godfrey P. 2003. Toward a Theory of Economic Self Reliance (ESR). Marriot School of Management. Brigham Young University.
Havighurst RJ. 1974. Development Task and Education. Third Edition. New York: David McKay Company, Inc.

Lukman Effendy. 2009. "Kinerja Petani Pemandu dalam Pengembangan PHT dan Dampaknya pada Perilaku Petani di Jawa Barat." Disertasi. Bogor: Sekolah Pascasarjana Institut Pertanian Bogor.

Lusthaus C, Adrien M, Anderson G, Carden FM. 2002. Organizational Assessment: A Framework for Improving Performance. IDRC. http://www.idrc.ca/en/ev-30266-2011do.html [diakses 25 April 2010].

Mardikanto T. 1993. Penyuluhan Pembangunan Pertanian. Surakarta: Sebelas Maret University Press.

Mardin. 2009. "Faktor-Faktor yang Berpengaruh pada Kemandirian Nelayan Ikan Demersal di Kecamatan Wangi-Wangi Selatan Kabupaten Wakatobi Sulawesi Tenggara." Tesis. Bogor: Sekolah Pascasarjana Institut Pertanian Bogor.

Mohamad Ikbal Bahua. 2010. "Faktor-Faktor yang Mempengaruhi Kinerja Penyuluh Pertanian dan Dampaknya pada Perilaku Petani Jagung di Provinsi Gorontalo." Disertasi. Bogor: Sekolah Pascasarjana Institut Pertanian Bogor.

Otto Iskandar. 2002. "Etos Kerja, Motivasi dan Sikap Inovatif Terhadap Produktivitas Petani." Tesis. Jakarta: IPWI

Robbins SP. 1996. Perilaku Organisasi edisi bahasa Indonesia, Jilid 1. Jakarta: Prenhallindo.

Siagian A, Siregar MA, Jumirah, Syarial E. 2002. "Studi Kaji Tindak Perubahan Perilaku Gizi Ibu dalam Upaya Peningkatan Konsumsi Sayuran pada Anak Usia Pra Sekolah." Jurnal Pemberdayaan Perempuan Volume 2, Nomor 2, Desember 2002:22-33.

Soedijanto. 2004. Menata Kembali Penyuluhan Pertanian di Era Pembangunan Agribisnis. Jakarta: Departemen Pertanian. 
Jurnal Penyuluhan, Maret 2012 Vol. 8 No.1

Nani Sufiani Suhanda. 2008. "Hubungan Karakteristik dengan Kinerja Penyuluh Pertanian di Provinsi Jawa Barat." Disertasi. Bogor: Sekolah Pascasarjana Institut Pertanian Bogor.

Tedy Rachmat Muliady. 2009. "Faktor-Faktor yang Mempengaruhi Kinerja Penyuluh Pertanian dan Dampaknya pada Perilaku Petani Padi di Jawa Barat." Disertasi. Bogor: Sekolah Pascasarjana Institut Pertanian Bogor.
Yusuf AE. 2008. Pengaruh Motivasi terhadap Peningkatan Kinerja. http://teknologikinerja.wordpress.com/2 008/05/06/pengaruh-motivasi-terhadappeningkatan-kinerja/. Diakses tanggal 19 Mei 2010.

Veithzal R. 2004. Performance Appraisal. Jakarta: Rajagrafindo Persada.

Wikipedia. 2009. Kinerja, http://id.wikipedia. org/wiki/Kinerja. Diakses 27 April 2009. 